\title{
Pneumonia by Aelurostrongylus abstrusus in a Leopardus tigrinus: Case study
}

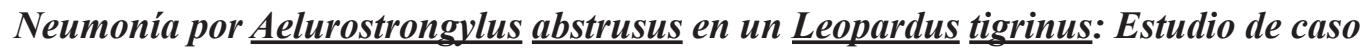

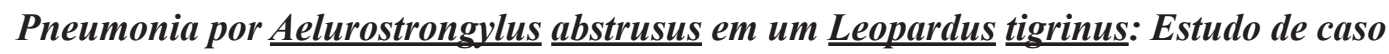

Diego F Rincón-Alarcón ${ }^{1}$ iD; Benjamín Doncel ${ }^{1}$ (D); Jesús A Cortés-Vecino²*(D).

\begin{abstract}
${ }^{1}$ Laboratorio de Patología Veterinaria, Facultad de Medicina Veterinaria y de Zootecnia, Universidad Nacional de Colombia-Sede Bogotá, Carrera 30 N. ${ }^{\circ}$ 45-03, Edificio 502, Código postal 11001, Bogotá, Colombia.

${ }^{2}$ Laboratorio de Parasitología Veterinaria, Departamento de Salud Animal, Facultad de Medicina Veterinaria y de Zootecnia, Universidad Nacional de Colombia-Sede Bogotá, Colombia.
\end{abstract}

To cite this article:

Rincón-Alarcón DF, Doncel B; Cortés-Vecino JA. Pneumonia by Aelurostrongylus abstrusus in a Leopardus tigrinus from Colombia: Case study. Rev Colomb Cienc Pecu 2023; 36(1): 13-21. DOI: https://doi.org/10.17533/udea.rccp.v35n4a04

\begin{abstract}
Anamnesis: A polytraumatized wild oncilla (Leopardus tigrinus) was admitted to the Unidad de Rehabilitación y Rescate de Animales Silvestres (URRAS) veterinary clinic of the Universidad Nacional de Colombia. Despite the medical efforts, the animal died six hours later. Clinical and laboratory findings: Necropsy examination revealed multiple white nodules of about 2 $\mathrm{mm}$ in diameter distributed on the visceral surface of lung caudal lobes. Histopathology revealed lymphoplasmacytic interstitial pneumonia with multiple coiled larvae of metastrongyloid nematodes in alveoli and bronchioles. First-stage Aelurostrongylus abstrusus nematode was identified in a fecal sample using the Ritchie copromicroscopic technique. Conclusion: This study reports an incidental severe pulmonary parasitism caused by A. abstrusus in a wild Oncilla (L. tigrinus). This is the first report of $A$. abstrusus infection associated with pathological lesions in a L. tigrinus from Colombia.
\end{abstract}

Keywords: Aelurostrongylus $\underline{\text { abstrusus; }}$ Leopardus tigrinus; little spotted cat; little tiger cat; lung; lungworm; lung parasitism; multiparasitism; nematode; oncilla; parasites; pneumonia; wildlife.

Received: December 21, 2021; accepted: February 2, 2022

*Corresponding author. Carrera 30 \# 45 - 03. Universidad Nacional de Colombia, Edificio 481. Laboratorio de Parasitología Veterinaria. Tel. +60(1) 3165000 ext. 15333. E-mail: jacortesv@unal.edu.co 


\section{Resumen}

Anamnesis: Un tigrillo silvestre (Leopardus tigrinus) politraumatizado fue ingresado en la clínica veterinaria Unidad de Rehabilitación y Rescate de Animales Silvestres (URRAS) de la Universidad Nacional de Colombia, donde posteriormente falleció. Hallazgos clínicos y de laboratorio: El examen de necropsia reveló múltiples nódulos blancos de aproximadamente $2 \mathrm{~mm}$ de diámetro, distribuidos en la superficie visceral de los lóbulos caudales del pulmón. La histopatología reveló neumonía intersticial linfoplasmocítica, con múltiples larvas enrolladas de nematodos metastrongiloides en alvéolos y bronquiolos. En la muestra fecal postmortem se identificó el nematodo Aelurostrongylus abstrusus en primera etapa por la técnica copromicroscópica de Ritchie. Conclusión: Este estudio reporta un parasitismo pulmonar severo incidental causado por $A$. abstrusus en un tigrillo silvestre (L. tigrinus). Este es el primer reporte de infección por A. abstrusus asociada con lesiones patológicas en un L. tigrinus en Colombia.

Palabras clave: Aelurostrongylus abstrusus; fauna silvestre; leopardo tigre; Leopardus tigrinus; multiparasitismo; nematodo; neumonía; oncilla; parasitismo pulmonar; parásitos; pulmón; tigrillo.

\section{Resumo}

Anamnese: Um Maracajá (Leopardus tigrinus) selvagem de vida livre foi internado na clínica veterinária Unidad de Rehabilitación y Rescate de Animales Silvestres (URRAS) da Universidad Nacional de Colombia devido a politraumatismo e o animal morreu. Achados clínicos e laboratoriais: O exame de necropsia revelou múltiplos nódulos brancos com cerca de $2 \mathrm{~mm}$ de diâmetro distribuídos na superfície visceral do pulmão dos lobos caudais. A histopatologia revelou pneumonia intersticial linfoplasmocitária com múltiplas larvas enroladas de nematóides metastrongilóides em alvéolos e bronquíolos. A amostra fecal post mortem para a técnica copromicroscópica de Ritchie permitiu a identificação do nematóide Aelurostrongylus abstrusus de primeiro estágio. Conclusão: Este estudo relata um grave parasitismo pulmonar incidental causado por A. abstrusus em um Maracajá selvagem de vida livre (L. tigrinus) da Colômbia. Este é o primeiro relato de infecção por A. abstrusus associada a lesões patológicas em L. tigrinus da Colômbia.

Palavras-chave: Aelurostrongylus abstrusus; fauna silvestre; gato do mato; gato-lagartixeiro; Leopardus tigrinus; maracajá; multiparasitismo nematóide; neumonia; parasitismo pulmonar; parasito; pintadinho; pulmão; oncilla. 


\section{Introduction}

Aelurostrongylus abstrusus is a nematode of the family Angiostrongylidae, within the Strongylida order. A. abstrusus is the most important nematode of the respiratory system in domestic cats (Felis silvestris catus) and is distributed worldwide (Traversa and Di Cesare, 2016). A. abstrusus cause occasional infections in several wildcats (Felis silvestris silvestris) from Europe (Traversa and Di Cesare, 2016), and also in serval cats (Leptailurus serval) and lions (Panthera leo) in Africa (Di Cesare et al., 2016). Infection by $A$. abstrusus has also been reported in South American Leopardus tigrinus, L. colocolo and in Puma yagouaroundi (Penagos-Tabares et al., 2018).

A. abstrusus is characterized by having an indirect life cycle with gastropods acting as intermediate hosts (Anderson, 2000); the L1 requires hosts such as land snails (Helix spp. and Lissachatina fulica), land slugs (Deroceras spp. or Arion spp. and Arion lusitanicus) (Jezewski et al., 2013; Valente et al., 2017) or a paratenic host such as rodents, reptiles, birds or frogs (Elsheikha et al., 2016). The A. abstrusus L3 is the infective larval stage for the definitive host (Anderson, 2000). The L1 penetrates snails and slugs, where they develop to L3. Once ingested, the infective L3 penetrates the intestinal mucosa of the definitive host and reaches to the lungs via lymphatics (Elsheikha et al., 2016).

Infection by $A$. abstrusus ranges from subclinical to severe clinical manifestations that may include abdominal breathing with an open mouth, intense coughing, sneezing, mucopurulent discharge, dyspnea, and hydrothorax. In more severe infections the animal may develop interstitial pneumonia (Traversa et al., 2008). Secondary bacterial infections can occur in severe cases, leading to death (Salamanca et al., 2003). Diagnosis is based on direct observation of the parasite in fecal samples or airway wash examination (Traversa and Di Cesare, 2016).

A. abstrusus was previously reported in domestic cats in Colombia (Penagos-Tabares et $a l ., 2018$ ), and more recently using the Baermann method in cats from Antioquia, Colombia (LópezOsorio et al., 2021). The parasite was observed in a case using the Ritchie technique (Salamanca et al., 2003). To the best of our knowledge, the present report is the first describing pathological lesions caused by $A$. abstrusus infection in a wild L. tigrinus from Colombia. L. tigrinus is currently considered a vulnerable species by the International Union for the Conservation of Nature (IUCN) (https://www.iucnredlist. org/species/54012637/50653881, accessed on November 5, 2021).

\section{Case presentation}

\section{Anamnesis}

A wild adult L. tigrinus from the Colombian Andes (Chipaque municipality, Cundinamarca province -North Latitude 4.4425, West Longitude 74.0414) was admitted with severe polytraumatism to the "Unidad de Rehabilitación y Rescate de Animales Silvestres (URRAS) of the Universidad Nacional de Colombia". The trauma was related to a car incident on the road.

\section{Clinical findings and diagnostic aids used}

Clinical examination revealed a deep wound with partial exposure of the omentum in the ventral region of the abdomen, pneumothorax, and complete fracture of the right ilium. The feline was subjected to surgical procedures to correct the bone fracture and omentum exposure. Despite the medical efforts, the animal died six hours later. The necropsy showed poor body condition, pale mucous membranes and multiple hematomas on the ventral abdomen. The $11^{\text {th }}$ and $12^{\text {th }}$ ribs on the right side of the rib cage were fractured, as well as the right ilium. The lung was partially collapsed, had diffuse congestion and edema, and $2 \mathrm{~mm}$ white nodules randomly distributed on the visceral pleura of caudal lobes and parietal pleura of the chest wall were observed (Fig. 1). Lung tissue samples were collected and fixed in $10 \%$ neutral buffered formalin, routinely processed and stained with hematoxylin and eosin (H\&E). 
Histopathology revealed multiple coiled metastrongyloid nematode larvae in the sagittal section (80-150 $\mu \mathrm{m})$ and cross-section (12-16 $\mu \mathrm{m})$ within the lumen of bronchi, bronchiole and alveoli of the lung (Fig. 2). The parasites were associated with severe multifocal lymphocytic and plasmacytic interstitial pneumonia. Some macrophages and neutrophils were also present. Moderate amount of mucus, cell debris and some desquamated epithelial cells were present in the lumen of the bronchi. In addition, alveolar atelectasis, moderate multifocal hemorrhage, edema and diffuse congestion were observed.

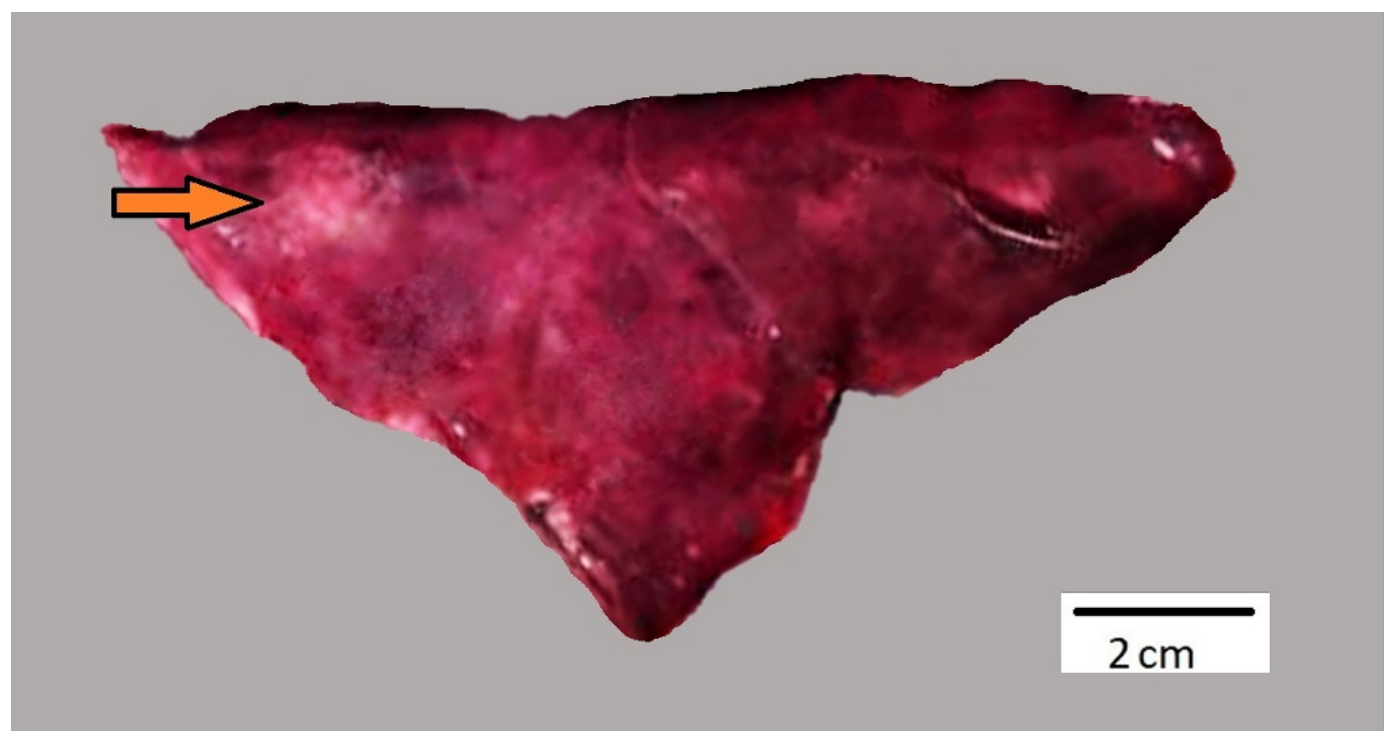

Figure 1. Lung of a Leopardus tigrinus naturally infected with Aelurostrongylus abstrusus. Multiple white nodules of approximately $2 \mathrm{~mm}$ in diameter were found near the caudal region (arrow) of the lung. Moderate diffuse pulmonary edema and congestion was also present. Bar, $2 \mathrm{~cm}$.

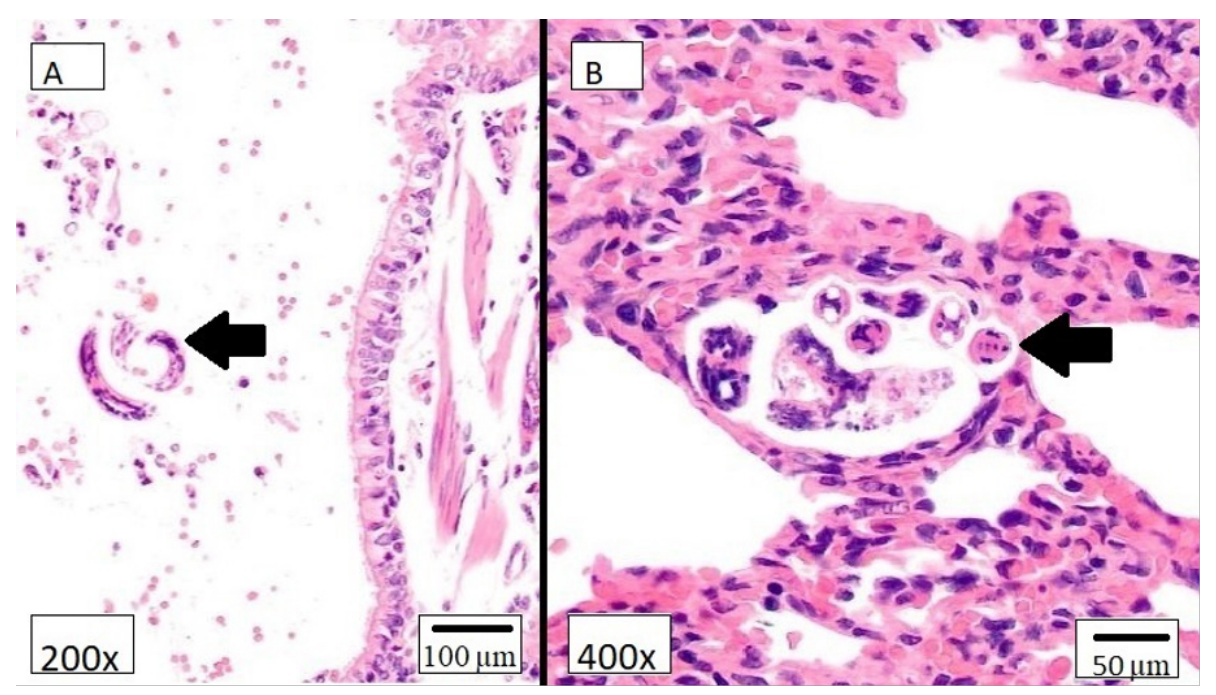

Figure 2. Severe verminous interstitial pneumonia in a Leopardus tigrinus caused by Aelurostrongylus abstrusus. The left panel shows coiled nematode larvae (arrow) in the lumen of the bronchi. The right panel shows moderate interstitial pneumonia, characterized by a lymphoplasmacytic infiltrate associated with intralesional parasitic forms (the arrow indicates a transversal portion of the nematode). H\&E stain. 
Following the Ritchie technique, the first step was comminution of the fecal sample, continuing with a straining with two layers of gauze. Fecal sediment was added with $10 \mathrm{ml}$ of $10 \%$ formalin, allowing five minutes for fixation of parasite structures and continuing with the addition of $3 \mathrm{ml}$ ether to the formalinized solution. The specimen was then centrifuged at slow speed (1,500 rpm for two minutes). Ether, superficial debris and formalin were completely decanted using an applicator to free superficial debris from the centrifuge tubes. The last step consisted in coverslip preparations. The remaining sediment was mixed with the fluid and poured onto a slide. A small drop of $2 \%$ iodine solution was placed near the drop of the sediment and mixed. Finally, the coverslip was pushed into the drop (Rictchie, 1948). A. abstrusus (Railliet, 1898) L1 were identified in the sample (Fig. 3). A. abstrusus L1 in feces were 360-400 $\mu \mathrm{m}$ long (median range: $370 \mu \mathrm{m}$ and $15-20 \mu \mathrm{m}$ in diameter). A. abstrusus appeared as a short and thick larva with sub-terminal spine on its S-shape, with conical head and granular content. Ancylostomatidae eggs (Ancylostoma spp., Uncinaria spp.) and Capillaria spp. were also observed.

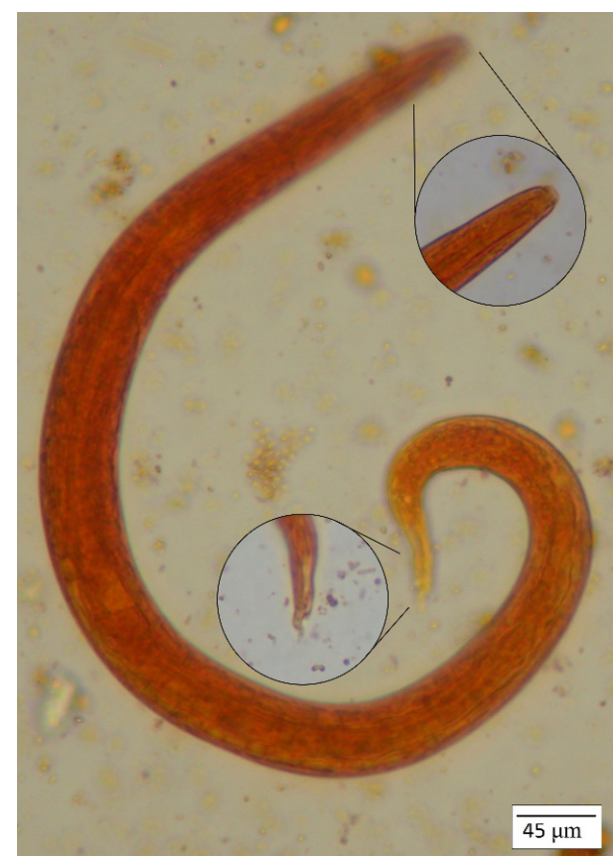

Figure 3. Morphological features of Aelurostrongylus abstrusus L1, measuring between 360-400 $\mu \mathrm{m}$ in length, detailing its tail and head. Bar, $10 \mu \mathrm{m}$.

\section{Discussion}

Although $A$. abstrusus is routinely found in domestic cats, its presence and potential pathological effects in wild cats is mostly unknown. In this report, the necropsy of an injured and finally dead L. tigrinus and the histopathological analysis of tissue samples revealed a number of lesions associated with severe A. abstrusus larvae infection. The intralesional parasitic larvae, observed in sagittal and cross-sections, caused a moderate interstitial pneumonia characterized by lymphocyte and plasmacyte infiltration. Parasitological studies confirmed the diagnosis. Since the animal was admitted to the clinic as a case of multiple traumas, which is also the most probable cause of death, the subclinical or clinical nature of $A$. abstrusus larvae infection remains unknown. Both pulmonary and gastrointestinal parasitosis could contribute to a poor body condition and weakening of the animal. Polytraumatism likely occurred when the animal and a vehicle collided on a roadway, worsening the health status and ending in the death of the animal. It is also possible that the anesthesia procedure conducted in the parasitized cat may have contributed to the deadly result. In this regard, previous studies report that anesthesia procedures were associated with death in domestic cats infected with $A$. abstrusus (Gerdin et al., 2011).

The A. abstrusus infection caused a lymphoplasmacytic interstitial pneumonia, which has also been reported in infected domestic cats (Philbey et al., 2014), where macrophages and eosinophils are associated with the parasites. Interstitial pneumonia has been reported mainly in subacute infections (Traversa et al., 2008), while a previous study described interstitial pneumonia in experimentally infected domestic cats (Schnyder et al., 2014). Tissue damages observed in L. tigrinus in the present case are very similar to those described in fatal natural or experimental cases in domestic cats (Schnyder et al., 2014; Traversa et al., 2014). Since all available reports of $A$. abstrusus infection have been documented in domestic cats, it was not possible to compare the pathological lesions of 
L. tigrinus with other wild cats; therefore, this report constitutes the first case of $A$. abstrusus infection in a wild feline in Colombia.

Diagnosis of pulmonary parasitosis caused by A. abstrusus larvae was established and supported by the data collected from the Ritchie technique along with the morphological characterization of the parasitic larvae. The Ritchie technique is known for increasing the likelihood of finding ova, cyst, and larvae, particularly in those specimens where they are present in insufficient numbers (Manser et al., 2016) and it is very useful in small size samples from wild animals with unknown parasitological records.

Molecular techniques such as PCR may be useful to confirm the identity of parasite species in animal tissues. Since extraction of DNA with suitable quality for PCR is not an easy procedure from formalin fixed and paraffin embedded tissues, recently, the morphological characterization of A. abstrusus and Angiostrongylus chabaudi and the location of adult nematodes was proposed as an alternative methodology to differentiate them (Wulcan et al., 2020). In addition, Giannelli and collaborators summarized the main lesions observed in different feline metastrongyloid infections and reported that A. abstrusus is usually present in respiratory bronchioles and alveolar ducts while species of Angiostrongylus mainly affects the pulmonary arteries (Giannelli et al., 2016). In the present case, no lesions were observed in blood vessels, whereas the presence of morulated eggs and larvae within the airways and alveolar ducts of the lung sections were indicative of $A$. abstrusus infection. Although the pathological lesions observed in L. tigrinus were mostly associated with $A$. abstrusus, it is important to note that the animal had a mixed parasitosis where Ancylostoma spp., Uncinaria spp., and Capillaria spp. may have also contributed to the poor body condition and was prone to traumatic coalition. In Brazil, up to 12 different parasite species in 14 fecal samples from L. tigrinus and a significant proportion of samples $(35.7 \%)$ were reported positive to $A$. abstrusus (Kusma et al., 2015).
Large scale epidemiologic studies are limited. Research in Italy found $A$. abstrusus in 1.82 (Site A) and $9.96 \%$ (Site B) of individual fecal samples of domestic cats (total sample size: 970; Di Cesare et al., 2011). In a large European study of lungworms in domestic cats, 1,990 animals were sampled, from which 613 (30.8\%) were positive for at least one parasite, while 210 (10.6\%) were infected with lungworms, and A. abstrusus was the species most frequently detected (78.1\%) (Giannelli et al., 2017). Recently, an experimental semi-nested PCR in blood samples of 171 domestic cats in Chile found 19.9\% molecular positivity (Barrios et al., 2021). In Brazil, two cases of 81 cats $(2.5 \%)$ were positive for metastrongyloid L1 at the Baermann's test, and one case was confirmed for A. abstrusus by a molecular test (Silva et al., 2021). Recently, an epidemiological study reported, for the first time, the presence of A. abstrusus, Troglostrongylus brevior, Crenosoma vulpis, and Angiostrongylus vasorum in the invasive giant African snail (L. fulica) in several locations of Colombia. $A$. abstrusus was found in $9.2 \%$ of L. fulica, with all positives present in a single municipality (Penagos-Tabares et al., 2019).

A. abstrusus has been reported in domestic cats in Colombia: A case in Quindío province from 121 samples processed (Echeverry et al., 2012), a case from Caquetá province (PenagosTabares et al., 2018), L1 was found in two cats from 473 sampled in Antioquia province using the Baermann method (López- Osorio et al., 2021), and the parasite was observed in a case using the Ritchie technique in Bogotá (Salamanca et al., 2003). The distribution of $A$. abstrusus in Colombia is unknown because the parasite is limited to case reports and few studies.

Currently, the impact of $A$. abstrusus in wild felids is unknown. Whether unnoticed relationships between wild and domestic cats may affect the health status of domestic cats is also unknown. The absence of epidemiological information on A. abstrusus in domestic and, probably, wild cats can be explained by at least two reasons: a predominance of subclinical infections, or underdiagnosed parasitosis (Traversa et al., 2008). 
Feline aelurostrongylosis is distributed worldwide and is often erroneously considered to be sporadic despite being a common infection (Di Cesare et al., 2011).

The 'dilution effect' hypothesis suggests that the net effects of biodiversity (including host and non-host species) reduce the risk of certain diseases in ecological communities (Keesing et al., 2006). There is evidence of this effect on parasites ecology (Civitello et al., 2015). Predators can induce trait-mediated indirect effects (TMIEs) on parasites and vice versa, and these effects could have important implications for disease emergence and parasite regulation (Raffel et al., 2008). Understanding the influence of predation on parasite transmission requires explicit examination of the host, parasite, and environmental conditions that influence parasite vulnerability (Orlofske et al., 2015). The role of intermediate or paratenic host in the ecology of A. abstrusus is not fully understood. This knowledge is highly relevant for a mega-diverse country such as Colombia.

Reports of $A$. abstrusus infection in wild felids diagnosed either by examining fecal samples or histopathology are very limited. Being the first report of lungworms in a wild felid from Colombia, this study warns about lungworm infection of wild cats and its potential impact on animal health and wildlife conservation.

\section{Declarations}

\section{Funding}

This study received no external funding or any specific grant from funding agencies in the public, commercial, or not-for-profit sectors. It was funded by the Parasitology and Pathology Laboratories of the Universidad Nacional de Colombia.

\section{Acknowledgments}

The authors express their gratitude to the staff of Unidad de Rehabilitación y Rescate de Animales Silvestres URRAS, to Óscar Cruz for technical support, to veterinary parasitologists, and to Gilberto Córdoba and Leonardo Bernal for technical support to veterinary pathologists.

\section{Conflicts of interest}

The authors declare they have no conflicts of interest with regard to the work presented in this report.

\section{Author contributions}

Necropsy, histopathology, literature review and manuscript writing: Diego F. RincónAlarcón. Histopathology, critical review and manuscript writing: Benjamín Doncel. Morphology characterization of nematode and eggs of other species, critical review and manuscript writing; Jesús A. Cortés-Vecino. All Authors revised the final version.

\section{References}

Anderson RC. Family Angiostrongylidae. In: Nematode Parasites of Vertebrates: Their Development and Transmission. CABI Publishing, Wallingford, Oxfordshire, UK, 2000; pp. 163-164. https://doi.org/10.1079/9780851994215.0001

Barrios N, Gómez M, Zanelli M, Rojas-Barón L, Sepúlveda-García $\mathrm{P}$, Adasme $\mathrm{M}$, Müller A, Rosenfeld C, González-Lagos C, Taubert A, Hermosilla C. A molecular survey on neglected Gurltia paralysans and Aelurostrongylus abstrusus infections in domestic cats (Felis catus) from southern Chile. Pathogens 2021; 10(9): 1195. https://doi.org/10.3390/pathogens10091195

Civitello DJ, Cohen J, Fatima H, Halstead NT, Liriano J, McMahon TA, Ortega CN, Sauer EL, Sehgal T, Young S, Rohr JR. Biodiversity inhibits parasites: Broad evidence for the dilution effect. Proc Natl Acad Sci U S A 2015; 112(28): 8667-8671. https://doi.org/10.1073/pnas. 1506279112

da Silva Lima W, Ferreira Farago EC, do Nascimiento Mesquita M, Duarte Pacheco A, Fernandes Nunes da Silva Malavazi P, Salvador Oliveira H, Morelli S, Colombo M, Di Cesare A, Figuereido de Souza S. First case of clinical cat Aelurrostrongylosis in the 
Brazilian Amazon: clinical and molecular insights. Pathogens 2021; 10(5): 595. https://doi.org/10.3390/pathogens10050595

Di Cesare A, Castagna G, Meloni S, Milillo P, Latrofa S, Otranto D, Traversa D. Canine and feline infections by cardiopulmonary nematodes in central and southern Italy. Parasitol Res 2011; 109 Suppl 1: s87-s96. https://doi.org/10.1007/s00436-011-2405-5

Di Cesare A, Laiacona F, Iorio R, Marangi M, Menegotto A. Aelurostrongylus abstrusus in wild felids of South Africa. Parasitol Res 2016; 115: 3731-3735. https://doi.org/10.1007/s00436-016-5134-y

Echeverry DM, Giraldo MI, Castaño JC. Prevalencia de helmintos intestinales en gatos domésticos del departamento del Quindío, Colombia. Biomédica. 2012; 32(3): 430-436. https://doi.org/10.1590/S0120-41572012000300013

Elsheikha HA, Schnyder M, Traversa D, Di Cesare A, Wright I, Lacher DW. Updates in feline aelurostrongylosis and research priorities for the next decade. Parasit Vectors 2016; 9(1): 389. https://doi.org/10.1186/s13071-016-1671-6

Gerdin JA, Slater MR, Makolinski KV, Looney AL, Appel LD, Martin NM, McDonough SP. Post-mortem findings in 54 cases of anesthetic associated death in cats from two spay-neuter programs in New York State. J Feline Med Surg 2011; 13(12): 959-966. https://doi.org/10.1016/j.jfms.2011.07.021

Giannelli A, Kirkiva Z, Abramo F, Latrofa MS, Campbell B, Zizzo N, Cantacessi C, DantasTorres F, Otranto D. Angiostrongylus chabaudi in felids: New findings and a review of the literature. Vet Parasitol 2016; 15: 188-192. https://doi.org/10.1016/j.vetpar.2016.09.007

Giannelli A, Capelli G, Joachim A, Hinney B, Losson B, Kirkova Z, René-Martellet M, Papadopoulus E, Farkas R, Napoli E, Brianti E, Tramponi C, Varcasia A, Alho AM, Carvalho LM, Cardoso L, Maia C, Mircean V, Mihalca AD, Miró G, Schnyder M, Cantacessi C,
Colella V, Cavalera MA, Latrofa MS, Annoscia G, Knaus M, Halos L, Beugnet F, Otranto D. Lungworms and gastrointestinal parasites of domestic cats: a European perspective. Int J Parasitol 2017; 47(9): 517-528. https://doi.org/10.1016/j.ijpara.2017.02.003

Kusma SC, Wrublewski DM, Teixeira VN, Holdefer DR. Parasitos intestinais de Leopardus wiedii e Leopardus tigrinus (felidae) da Floresta Nacional de Tres Barras, SC. Luminária 2015; 17: 82-95; [Access date: 18 Dec. 2021] URL: http://periodicos.unespar.edu.br/index.php/ luminaria/article/view/520/374

Jezewski W, Búnkowska-Gawilk K, Hildebrand J, Perec-Matysiak A, Laskowski Z. Intermediate and paratenic host in the life cycles Aelurostrongylus abstrusus in natural environment. Vet Parasitol 2013; 198(3-4): 401-405. https://doi.org/10.1016/j.vetpar.2013.09.003

Keesing F, Holt RD, Ostfeld RS. Effects of species diversity on disease risk. Ecol Lett 2006; 9(4): 485-498. https://doi.org/10.1111/j.1461-0248.2006.00885.x

López-Osorio S, Navarro-Ruiz JL, Rave A, Taubert A, Hermosilla C, Chaparro-Gutiérrez JJ. Aelurostrongylus abstrusus infections in domestic cats (Felis silvestris catus) from Antioquia, Colombia. Pathogens 2021; 10: 337. https://doi.org/10.3390/pathogens 10030337

Manser MN, Santos-Sáenz AC, Chiodini PL. Faecal parasitology: Concentration methodology needs to be better standardizes. PLoS Negl Trop Dis 2016; 10(4): e0004579. https://doi.org/10.1371/journal.pntd.0004579

Penagos-Tabares F, Lange MK, ChaparroGutiérrez JJ, Taubert A, Hermosilla C. Angiostrongylus vasorum and Aelurostrongylus abstrusus: Neglected and underestimated parasites in South America. Parasit Vectors 2018; 11:208. https://doi.org/10.1186/s13071-018-2765-0

Penagos-Tabares F, Lange MK, Vélez J, Hirzmann J, Gutiérrez-Arboleda J, Taubert A, Hermosilla C, Chaparro-Gutiérrez JJ. The invasive giant 
African snail Lissachatina fulica as natural intermediate host of Aelurostrongylus abstrusus, Angiostrongylus vasorum, Troglostrongylus brevoir, and Crenosoma vulpis in Colombia. PLoS Negl Trop Dis 2019; 13(4): e0007277. https://doi.org/10.1371/journal.pntd.0007277

Philbey AW, Krause S, Jefferies R. Verminous pneumonia and enteritis due to hyperinfection with Aelurostrongylus abstrusus in a kitten. J Comp Pathol 2014; 150(4): 57-360. https://doi.org/10.1016/j.jcpa.2014.02.001

Orlofske SA, Jadin RC, Johnson PTJ. It's a predator-eat-parasite world: how characteristics of predator, parasite and environment affect consumption. Oecologia 2015; 178(2): 537-547. https://doi.org/10.1007/s00442-015-3243-4

Raffel TR, Martin LB, Rohr JR. Parasites as predators: unifying natural enemy ecology. Trends Ecol Evol 2008; 23(11): 610-618. https://doi.org/10.1016/j.tree.2008.06.015

Ritchie LS. An ether sedimentation technique for routine stool examination. The Bulletin of the U.S. Army Medical Department 1948; 8(4): 326; [Access date: 18 Dec. 2021] URL: https://stimson.contentdm.oclc.org/digital/ collection/p15290coll6/id/3672

Salamanca JA, Gil B, Cortés JA. Parasitosis pulmonar por Aelurostrongylus abstrusus en un felino. Reporte de caso. Rev Med Vet Zoot 2003; 50: 30-34; [Access date: 18 Dec. 2021] URL: https://revistas.unal.edu.co/index.php/remevez/ article/view/27965/28222
Schnyder M, Di Cesare A, Basso W, Guscetti E, Riond E, Glaus T, Crisi P, Deplazes P. Clinical, laboratory and pathological findings in cats experimentally infected with Aelurostrongylus abstrusus. Parasitol Res 2014; 113(4): 1425-1433. https://doi.org/10.1007/s00436-014-3783-2

Traversa D, Lia D, Iorio R, Boari A, Paradies P, Capelli G, Avolio S, Otranto D. Diagnosis and risk factors for Aelurostrongylus abstrusus (Nematoda : Strongylida) infection in cats from Italy. Vet Parasitol 2008; 153(1-2): 182-186. https://doi.org/10.1016/j.vetpar.2008.01.024

Traversa D, Romanucci M, Di Cesare A, Malatesta D, Cassini R, Iorio R, Seghetti M, Della Salda L. Gross and histopathological changes associated with Aelurostrongylus abstrusus and Troglostrongylus brevior in a kitten. Vet Parasitol 2014; 201(1-2): 58-162. https://doi.org/10.1016/j.vetpar.2014.01.020

Traversa D, Di Cesare A. Diagnosis and management of lungworm infections in cats. J Feline Med Surg 2016; 18(1): 7-20. https://doi.org/10.1177/1098612X15623113

Valente R, Díaz JI, Salomón OD, Navone GT. Natural infection of the feline lungworm Aelurostrongylus abstrusus in the invasive snail Achatina fulica from Argentina. Vet Parasitol 2017; 235: 17-19. https://doi.org/10.1016/j.vetpar.2017.01.006

Wulcan JM, Timmins A, Dennis MM, Thrall MA, Lejeune M, Abdu A, Ketzis JK. First report of Aelurostrongylus abstrusus in St. Kitts. Vet Parasitol Reg Stud Reports 2020; 19: 100366. https://doi.org/10.1016/j.vprsr.2019.100366 